\title{
Kadın İşgörenlerin Karşılaştığı Sorunların Örgütsel Sessizlikleri Üzerindeki Etkisi: Bodrum'daki Otel İşletmelerinde Bir Araştırma
}

\author{
The Effects of The Problems Faced by Female Employees on Their Organizational \\ Silence: A Research on Hotels in Bodrum
}

\author{
Doç. Dr. Evren GÜÇER ${ }^{1}$, Dr. Öğr. Üyesi Yasin KELEŞ², Öğr. Gör. Şerif Ahmet \\ DEMIRDAĞ $\breve{3}^{3}$, Öğr. Gör. Nazik ÇELİKKANAT ${ }^{4}$
}

\begin{abstract}
Özet
Çalışma hayatındaki kadın işgörenler zorlu çalışma koşullarının yanı sıra sırf kadın olmaktan kaynaklanan birçok sorunla da karşılaşabilmektedir. Bu çalı̧̧manın amacı, kadın işgörenlerin karşılaştı̆̆ sorunların analiz edilmesi ve karşılaştıkları bu sorunların örgütsel sessizlikleri üzerindeki etkisinin belirlenmesidir. Çalışmada veri toplama yöntemi olarak anket tekniğinden yararlanılmış ve Bodrum'daki 3-4-5 yıldızlı otel işletmelerinde çalışan toplam 429 kadın işgören üzerinde uygulanmıştır. Elde edilen bulgulara göre, kadın işgörenlerin işleriyle ilgili karşılaştığ 1 sorunların başında "aldıkları ücretin yetersiz olması", "karşılaştıkları farklı sorunların ruh hallerini olumsuz etkilediğini düşünmeleri" ve "zaman zaman kapasitelerinin üstünde iş yapmak zorunda kaldıkları" gelmektedir. Otel işletmelerinde çalışan kadın işgörenler örgütsel sessizlikle ilgili olarak iş ortamı boyutunda "duygu ve düşüncelerini dile getirmelerinin yüksek düzeyde örgütsel öğrenme ve gelişmeyi destekleyeceğine" inanmaktadır. Bunun yanında, örgütsel sessizliğin duygu boyutuyla ilgili olarak "belirli konular hakkında konuşmaktan kaçındıklarını" belirtmişlerdir. Yapılan korelasyon analizi sonucunda karşılaşılan sorunlar ve örgütsel sessizlik arasında çok kuvvetli ve pozitif yönlü; karşılaşılan sorunların psikolojik boyutu, fiziksel boyutu ve kişisel boyutu ile örgütsel sessizlik arasında ise kuvvetli ve pozitif yönlü anlamlı ilişkiler olduğu tespit edilmiştir.
\end{abstract}

Anahtar Kelimeler: Kadın işgörenler, sorunlar, örgütsel sessizlik, oteller

\begin{abstract}
In the working life, female employees may face many problems arising from being a woman, in addition to the difficult working conditions. The purpose of this study is to analyze the problems faced by female employees and to determine the impact of these problems on their organizational silences. Survey technique was used as data collection method in this study and the survey technique was applied on total of 429 female employees working in 3-4-5-star hotels in Bodrum. According to the findings, the problems faced by female employees related to their work are "insufficient wages", "their thoughts about different problems they encounter affects their moods" and "occasionally they have to work above their capacities". Female employees who work in hotels believe that "expressing emotions and thoughts will support a high level of organizational learning and development" in the terms of organizational silence. Besides, the female employees have stated that "they are afraid to talk
\end{abstract}

\footnotetext{
${ }^{1}$ Gazi Üniversitesi Turizm Fakültesi, evrengucer@gazi.edu.tr, Orcid ID: orcid.org/0000-0001-5454-6162

${ }^{2}$ Ondokuz Mayıs Üniversitesi, Turizm Fakültesi, yasin.keles@omu.edu.tr, Orcid ID: orcid.org/0000-0002-6879-448X

${ }^{3}$ Giresun Üniversitesi, Bulancak Kadir Karabaş U.B.Y.O., serif.demirdag@giresun.edu.tr, Orcid ID: orcid.org/0000-00034317-5727

${ }^{4}$ Giresun Üniversitesi, Bulancak Kadir Karabaş U.B.Y.O., nazik.celikanat@ giresun.edu.tr, Orcid ID: orcid.org/0000-00032606-3088
} 
about some certain subjects" in the emotional dimension of organizational silence. As a result of the correlation analysis, there is a very strong and positive relationship between the problems faced by female employees and their organizational silence, and also the strong and positive relationship were found between the dimensions (psychological, physical and personal) of the problems faced and the organizational silence.

Keywords: Female employees, problems, organizational silence, hotels

\section{Giriş}

Bir toplumun kalkınmasında nüfus ve işgücü faktörleri önemli bir rol oynamaktadır. Türkiye nüfusunun \%49,8'ini kadınlar oluşturmaktadır (TÜIK, 2017a). Türkiye İstatistik Kurumu'na (TÜIK) göre, 2016 yılında kadın istihdam oranı toplam nüfusun \%30,6's1 iken, kadınların işgücüne katılım oranı toplam nüfusun \%36,6's1 oranında (TÜIK, 2017b) olup dünya ortalamasının (\%46) altındadır (ILO, 2016).

Kadın nüfusunun işgücüne katılma oranının yüksek olması ekonomiler açısından istenilen bir durumdur. Fakat kadını işgücü piyasasının dışına iten; cinsiyet ayrımcılığı, eğitim ve meslek edinmedeki firsat eşitsizliği, tolumun ataerkil bir yapıya sahip olması, medeni durum gibi pek çok sebep bulunmaktadır (Korkmaz ve Korkut, 2012: 42; Çakır, 2008: 42; Dalkıranoğlu ve Çetinel, 2008: 277; Sayın, 2011: 24; Demirkol vd., 2004: 77). Çünkü çalışan bir kadının iş sorumluluklarının yanı sıra özel yaşamında da eş, anne, kız çocuk, gelin, abla, kayınvalide olmak gibi aile içi ilişkilerden kaynaklanan rolleri bulunmaktadır. Dolayısıyla, kadınların işgücüne katıldıkları andan itibaren hem kariyerlerini hem de aile yaşamlarını dengede tutabilmek için fazladan çaba harcamaları gerekebilmektedir. Aile ekonomisine katkıda bulunmak, kendi ekonomik özgürlügünü kazanmak gibi nedenlerle çalışma yaşamına giren kadınlar, üstlenmiş oldukları bu sorumluluklar dışında, çalışma hayatlarında da birtakım sorunlarla karşılaşabilmektedir. $\mathrm{Bu}$ sorunların belirli bir bölümü genellikle fiziksel güçlerinden, belirli bir bölümü de cinsiyet ayrımcılığından kaynaklanabilmektedir. Kaynağı ne olursa olsun, kadın çalışanlar karşılaştıkları sorunlar karşısında genellikle tepki verme eğilimi gösterirken, bazı çalışanlar ise tepkisiz ve sessiz kalabilmektedir. Örneğin, Pelit vd. (2016: 43)'nin çalışmasında, kadınlar iş yaşamında karşılaştığ 1 sorunlar neticesinde tepki olarak iş bırakma eğiliminde bulunurken; Demir (2014: 1108)'in çalışmasında ise tepki ya da tepkisizlik olarak örgütsel sessizlik davranışı gösterebildikleri tespit edilmiştir. Örgütsel sessizlik, işgörenlerin yapmakla yükümlü oldukları işleri veya örgütteki diğer faaliyetleri ile ilgili fikir, düşünce, kaygı ve önerilerini dile getirememeleri durumunda ortaya çıkan bir davranıştır (Önal, 2015: 81). $\mathrm{Bu}$ davranış örgütsel değişimin ve gelişimin önünde oldukça önemli bir engel oluşturmaktadır (Kahveci ve Demirtaş, 2013a; 63). Bu çalışmada, otel işletmelerinde çalışan kadın işgörenlerin karşılaştığı sorunlar ve bu sorunların örgütsel sessizlikleri üzerindeki etkisi incelenmiştir. Bunun yanı sıra konuyla ilgili yapılacak iyileştirmeler ve geliştirilecek politikalar açısından ilgili kişi ve kuruluşlar için önerilerde bulunulmuştur.

\section{Kadın İşgücünün Çalıșma Yaşamındaki Yeri}

Kadınlar her dönemde ve her toplumda, çeşitli çalışma biçimleri ile üretim faaliyetleri içerisinde yer almıştır (Özçatal, 2011: 22). Sanayi devrimi ve sonrasında oluşan teknolojik, ekonomik ve toplumsal değişiklikler, kadınlara ekonomik faaliyetlere ücret karşılığı daha fazla katılma imkânı sağlamış ve "ücretli kadın işgücü” kavramının doğmasına 
yol açmıştır (Parlaktuna, 2010: 1217). Kadının tarım dışı sektörlerde çalışmaya katılması, endüstrileşme ile başlamışsa da özellikle II. Dünya Savaşı sonrası hız kazanmıştır (Kocacık ve Gökkaya, 2005: 198). Türkiye'de kadınlar cumhuriyetin kuruluşundan sonra eğitim, siyasi temsil ve istihdam alanlarında daha geniş olanaklar elde etmiştir (Bebekoğlu ve Wasti, 2002: 7).

Nüfus olarak kadınlar dünya nüfusunun yaklaşık yarısına sahip olmalarına rağmen, toplumsal ve ekonomik yaşama katılımları oransal olarak erkeklerden daha düşüktür (Örücü vd., 2007: 118). Kadınların toplumsal ve ekonomik alanda istenilen düzeyde katılımlarının olmamasının nedenleri çok çeşitlidir. Bu nedenler göreceli olmakla beraber, toplumsal ve kültürel yapının özelliklerinin de bir sonucudur (Kocacık ve Ayan, 2011: 465). Söz konusu nedenlerin başında medeni durum, $0-5$ yaş arası çocukların varlığı ve sayısı, eğitim seviyesi, ücret eşitsizliği, kadınların çalışmasına yönelik çevrenin tutumu ve kadın istihdamını arttırmaya yönelik yasal düzenlemelerin yetersizliği gibi faktörler gelmektedir (Korkmaz ve Korkut, 2012: 61). Cinsiyete dayalı iş bölümü, evli kadına ev işleri ve çocuk bakımı gibi görevler yüklerken, evin geçimi ise erkeğin görevi olarak görülmektedir (Özçatal, 2011; 24). Aile yaşamında ev ve çocuk sorumluluğunun kadına yüklenmiş olması, kadının iş hayatına katılmasına veya iş hayatında kariyer yapmasına engel olmaktadır (Dalkıranoğlu ve Çetinel, 2008: 280). İş̧ücüne katılımda, eğitim durumunun da önemli bir faktör olduğu görülmektedir (Ayvaz Kızılgöl, 2012: 100). Yapılan bazı çalışmalar (Koray, 1992; Kuzgun ve Sevim, 2004; Çakır, 2008; Gül vd., 2014) eğitim düzeyi ilerledikçe işgücüne katılım oranının yükseldiğini göstermektedir. Ayrıca, toplumun kadına bakış açısı da kadının işgücüne katılımında etkilidir (Korkmaz ve Korkut, 2012: 51).

Kadınlar, tarih boyunca cinsiyet ayrımcılığ 1 ve eşitsizliklerle karşı karşıya kalmışlardır. Birçok ülkede eşitliğe yönelik gelişmeler, yeni uygulamalar kaydedilmesine rağmen, kadınlar hala ayrımcilığa, cinsel istismara ve aile içi şiddete maruz kalabilmektedirler (Kahraman, 2010: 34). Buna karşın kadınların işgücüne katılımının artırılması, bireysel ve toplumsal açıdan sürdürülebilir kalkınmanın gerçekleştirilebilmesinde önemli bir unsur haline gelmiştir (Karabıyık, 2012:232). İnsan unsurunun önemli olduğu ve bir hizmet sektörü olan turizm sektöründe de kadın çalışanların önemi göz ardı edilemez. Ancak birçok sektörde olduğu gibi kadınlar, turizm sektöründe de fiziksel, psikolojik ve duygusal boyutlarda birtakım sorunlarla karşılaşabilmektedir. Kadın işgörenlerin karşılaş̧ığı sorunların analiz edilerek ortaya konması konuyla ilgili geliştirilecek politikalar ve yapılacak iyileştirmeler açısından önem taşımaktadır.

\section{Kadın İşgörenlerin Çalışma Yaşamında Karşılaştıkları Sorunlar ve Turizm Sektöründe Mevcut Durum}

Kadın işgörenler her türlü çalışma ortamında erkek işgörenlerin yaşadığ 1 sorunları yaşamanın yanı sıra, kadın olmalarından kaynaklı birçok farklı sorunla da mücadele etmek zorunda kalmaktadır (Yılmaz vd., 2008: 91). Kadınlar çalışma yaşamlarında; uzun çalışma saatleri, eşit işe eşit ücret ödenmemesi, düşük ücretle erkeklerin alternatifi olarak görülmesi, işe alınmada eşitlik ilkesinin uygulanmaması, annelik ve aile yaşamının kadının çalışmasını kısıtlaması, terfi ettirilmemesi, taciz gibi sorunlarla karşı karşıya kalmaktadır (Yılmaz vd., 2008: 91; Gül, vd., 2014: 174; Küçük, 2015: 3). Kadınların sahip olduğu bilgi ve becerileri dikkate alınmadan, aile ilişkisinin incelenmesi ve bunun neticesinde genellikle bekâr ve genç olan kadınların tercih edilmesi, işe alımlarda eşitlik ilkesinin uygulanmıyor olmasına örnek 
olarak gösterilebilir. Bu durumda evli kadınların aile yaşantılarını aksatmayacak düzeyde iş bulmaları, bekâr kadınlara oranla daha zor olabilmektedir. (Alparslan vd., 2015: 70).

Kadınların, iş ve aile yaşamı arasında denge kurmada genellikle zorlandıkları görülmektedir (Aydın Tükeltürk ve Perçin, 2008: 114). Kadınlar evlendiklerinde, toplum buna uygun bir statü ve davranış bekler. Anne, ev hanımı, eş gibi birden fazla kimlik ve sorumlulukla birlikte çalışma yaşamında var olmaya çalışan kadınlar, birçok sorunla karşı karşıya kalabilmektedir (Gül vd., 2014: 174). Dolayısıyla, çalışma yaşamları dışında, yoğun iş temposundan kaynaklı olarak sosyal yaşantılarını (aile, dostluklar gibi ilişkilerini) bazen arka plana atabilmektedirler (Küçük, 2015: 14).

Kadın işgörenlerin turizm sektörü başta olmak üzere karşılaştığı sorunlarla ilgili Türkiye ve dünyada birçok çalışma yapılmıştır. Bazı araştırmacılar, kadın çalışanların karşılaştıkları kariyer engelleri ve cam tavan sendromunu (Örücü vd., 2007; Aydın Tükeltürk ve Perçin, 2008); bazıları kadın işgörenlerin karşılaştıkları sorunların iş bırakma eğilimine etkisini (Pelit vd., 2016); bazıları kadının çalışma yaşamından dışlanmasını (Çakır, 2008); bazıları cinsiyet ayrımcılığını (Bebekoğlu ve Wasti, 2002; Parlaktuna, 2010; Alparslan vd., 2015); bazıları kadınların çalışmasına karşı tutumlarla dini yönelim arasındaki ilişkiyi (Kuzgun ve Sevim, 2004); bazıları çalışma yaşamında stres ve kadın çalışanlar üzerindeki etkisini (Cam, 2004); bazıları kadının çalışma yaşamında karşılaştı̆̆ genel sorunları (Demirkol vd., 2004; Maqsood vd., 2005; Kocacık ve Gökkaya, 2005; Y1lmaz vd., 2008; Kocacık ve Ayan, 2011; Nawaz vd., 2013; Gül vd., 2014; Mittal vd., 2015) incelemişlerdir. Yapılan bu çalışmalar genel olarak değerlendirildiğinde, kadınların çalışma hayatında karşılaşmış olduğu sorunların zamanla daha büyük örgütsel sorunlara yol açabileceğinin vurgulanmış olduğu görülmektedir. Bazı kadın işgörenler, karşılaştıkları bu sorunlarla baş etme noktasında olağanüstü bir çaba gösterirken, bazıları ise belirli tedirginlik sebebiyle (işyerinde dışlanma, işletmede sorun çıkarıcı ve şikâyetçi birisi gibi görünme, saygı ve güven kaybına uğramak, terfi edememek, işini kaybetme, aile huzurunun bozulması, adının kötüye çıkması gibi korkular) sessiz kalmayı tercih ederek, bu sorunlara boyun eğme yoluna gitmektedir.

Hizmet sektörü içinde yer alan turizm sektöründe, her geçen gün kadın çalışanların sayısı giderek artmaktadır (Aydın Tükeltürk ve Perçin, 2008: 114). Diğer sektörlerde olduğu gibi turizm sektöründe de kadın işgörenler bireysel ve toplumsal sorunların yanı sıra, işle ilgili sektörel sıkıntılar ve cinsiyete dayalı ayrımcılığa dayanan sorunlar yaşamaktadır (Pelit vd., 2016: 47). Demirkol vd. (2004: 85)'nin yaptıkları çalışmada; iş yükü ve çalışma sürelerinin fazlalığı, sorumluluk verilmesine karşın yetkinin azlığı, sendikal hakkın fazla yaygın olmaması, hizmet içi eğitim olanağı yetersizlikleri, iş güvencesi-ücret-rotasyon uygulanma imkânları yetersizlikleri, taciz olayları gibi önemli sorunların baş gösterdiği sonucuna ulaşılmıştır. Söz konusu sorunlar, kadınlarda sessizliğe yol açabilmektedir.

\section{3. Örgütsel Sessizlik}

Örgütler, sürdürülebilir rekabet avantajı sağlamak için; sürekli değişen çevresel tehditlere cevap verebilen, sahip olduğu bilgi, fikir ve görüşünü örgüt ve çalışma arkadaşları ile paylaşmaktan korkmayan çalışanlara daha çok ihtiyaç duymaktadır (Acaray vd., 2015: 152). Çünkü çalışanların fikirlerini, görüşlerini açıkça dile getirmemeleri, örgütün devamlılığını ve gelişmesini engellemektedir. 
Ancak, tam aksinin doğru olduğuna inanan ve çalışanlarını örgütsel bir sessizlik kültürü içinde baskılayan örgütler de mevcuttur (Algın, 2014: 1; Dilek ve Taşkıran, 2016: 403).

Örgütte çalışan bireylerin davranışlarından biri olan örgütsel sessizlik, örgütün faaliyetlerini etkileyen kavramlardan birisini oluşturmaktadır (Bayın vd., 2015: 249). Örgütsel sessizlik, çalışanların örgüt ile ilgili görüş ve düşüncelerini paylaşmamaları ve örgütün kararlarından kendilerini uzak tutmaları (Morrison ve Milliken, 2000: 707) olarak tanımlanmaktadır. İşgörenlerin örgütsel sessizliği tercih etmeleri ya da sessiz kalmalarını açıklayabilecek çeşitli teoriler geliştirilmiştir. Literatürde öne çıkan teoriler, "Bekleyiş Teorisi", "Fayda-Maliyet Analizi Teorisi", "Sessizlik Sarmalı Teorisi" ve "Kendini Uyarlama Teorisi” olarak değerlendirilebilir.

Victor H. Vroom (1964) tarafından geliştirilen “Bekleyiş Teorisi”ne göre, çalışanlar verdikleri emek ve çabaları karşıllğında işten elde etmeyi umduğu ve arzuladığı değer, ödül, amaç gibi beklentiler içerisine girmektedir ve bu beklentiler karşılandıkça çalışanların işlerinden tatmin olması beklenmektedir (Kuşluvan ve Kuşluvan, 2005: 184). Bekleyiş teorisi, performansla sonuç arasındaki ilişkiye ağırlık veren bir teori olduğu için, bu teorinin uygulanması ancak performans ile varılacak sonuç arasında açıkça hissedilen ve işleyen bir ilişki ile mümkün olabilmektedir (Demirel, 1989: 23). Diğer taraftan işgörenler, yöneticileri tarafindan alacakları tepkilerin özelliğine göre de davranışlarını sürdürme ya da bitirme eğilimi göstermektedir (Altok, 2009: 76). Dolayısıyla, bekleyiş teorisine göre işgörenler verdikleri emek ve çabanın neticesinde elde edecekleri kazanımlara bağlı olarak örgütsel sessizlik davranışı da sergileyebilecektir.

"Fayda-Maliyet Analizi Teorisi”ne göre çalışanlar, örgüt ile ilgili konularda fikirlerini ifade ederken fayda-maliyet analizi yapmaktadır. Örgüt ile ilgili fikirlerini ifade ettiklerinde sağlayacakları faydaları ve maliyetleri karşılaştırarak, konuşmayı veya sessiz kalmayı tercih ederler. Konuşmanın olası sonuçları karşısında dışlanma, karşıt görüşler, itibarın azalması, çatışma korkusu vb. durumlarla (Premeaux ve Bedeian, 2003: 1540) karşılaşmaları muhtemeldir. Ayrıca işgörenin terfi kaybı ve işini kaybetme de ödenen bedeller arasındadır (Çakıcı, 2007: 152). Örgütsel sessizlik de söz konusu olumsuz durumlardan kaynaklı olarak ortaya çıkabilmektedir.

İşgörenlerin çalışma yaşamlarında sessiz kalmayı tercih etmelerini açıklayan diğer önemli bir teori de Noelle-Neumann (1974: 43-51)'1n geliştirdiği "Sessizlik Sarmall Teorisi"dir. Bu teori kapsamında insanlar, çoğunluğun içerisinde yer almadıkları zaman, başkalarının kendilerine inanmayacağını ya da fikirlerinin ciddiye alınmayacağını ve bunun neticesinde yalnız kalacaklarını düşünmelerinden kaynaklı olarak sessizlik davranışı gösterebilmektedirler (Dönmez, 2016: 39). Bu davranış kültürlere göre farklılık gösterebilir.

“Kendini Uyarlama Teorisi”nde ise işgörenler, çevre ve iş ortamına göre davranışlarında değişiklikler göstermektedir (Greenberg ve Baron, 2003: 90). Çünkü 
çoğu insan için toplumda kabul görmek ve beğenilmek önemli bir rol oynamaktadır (Çakıcı: 2007: 154). Kendini uyarlama düzeyi düşük olan bireyler, düşünce ve duygularını yansıtma eğiliminde olan kişilerdir. Kendini uyarlama düzeyi yüksek olan bireyler ise bu kişilere göre daha az konuşmayı tercih etmektedir (Premeaux ve Bedeian, 2003: 1541).

Çalışanların sessiz kalmayı tercih etme nedenlerinin başında; kişisel, örgütsel ve yönetsel faktörlerin etkin rol oynadığı ifade edilmektedir (Arlı, 2013: 80; Erol ve Köroğlu, 2013: 61; Üçok ve Torun, 2015: 31-32). Bu anlamda sessizliği etkileyen bireysel faktörleri "geçmiş tecrübeler, yöneticilere duyulan güvensizlik, ötelenme/dışlanma korkusu, konuşmanın riskli görülmesi, ilişkileri zedeleme korkusu ve işgörenlerin kişilik özellikleri”; örgütsel faktörleri "adaletsizlik kültürü ve sessizlik iklimi" oluştururken, yönetsel faktörleri ise "negatif geri bildirim alma korkusu ve yöneticilerin örtük inançlarının" oluşturduğu belirtilmektedir (Önal, 2015: 106-117). Özellikle yönetsel yetersizliğe sahip olan örgütlerde işgören sessizliğinin daha yoğun yaşandığı bilinmektedir (Demir, 2014: 1100). Kurumda hâkim olan katı hiyerarşik yapıdan kaynaklı olarak çalışanlar, işle ilgili konularda yöneticileriyle konuşmaktan çoğunlukla çekinmektedir (Üçok ve Torun, 2015: 33). Diğer taraftan çalışanlar üzerindeki baskı arttıkça çalışanların kendini korumaya ve korkuya dayalı sessizlik davranışının artığ sonucuna ulaşıldığ 1 belirtilmektedir (Çavuş vd., 2015: 19). Alparslan ve Kayalar (2012)'ın çalışmasına göre; örgütsel sessizliğin oluşumundaki temel faktör üst yönetim olarak ifade edilmektedir. Sonuç olarak gerek hizmet sektöründe gerekse diğer sektörlerde faaliyet gösteren örgütlerde pek çok nedenden meydana gelen stresin hem bireylere hem de örgüte olumsuz sonuçlar doğuracağı açıktır (Kılıç vd., 2013: 19).

Çalışanların sergilediği sessizlik davranışı, örgütlerin üstün performans elde etmek için çalışanlarının çeşitli yeteneklerinden yararlanma girişiminde büyük engeller oluşturmaktadır (Amah ve Okafor, 2008: 1). İşgörenlerin örgütte sessiz kalmayı seçmesiyle ilgili olarak ise birçok faktör sayılabilir (Eroğlu vd., 2011: 100). Örneğin, işgörenlerin örgüte bağlılı̆̆ının olmaması (Bryant ve Cox, 2004: 588) ve örgütte dile getirecekleri konuların bir fark yaratmayacağını düşünmeleri (Van Dyne vd., 2003: 1363) sessizlik nedenleri arasında sayılabilir. Ulusal ve kültürel normların işgörenlerin örgütsel sessizlikleri üzerinde (Çakıc1, 2007: 155) etkili olabileceği düşünülebilir. Diğer taraftan, işgörenler imajının zarar görmesi, olumsuz olarak nitelendirilme, ilişkilerinin zarar görmesi, cezalandırılma ve diğerleri üzerinde olumsuz etki yaratma kaygısından dolayı sessiz kalma davranışı sergileyebilmektedir (Aktaş ve Şimşek, 2014: 26). Ayrıca, mobbinge maruz kalma durumları da işgörenleri sessizliğe iterek, örgütte yeni fikirlerin, sinerjinin ve yaratıcıllı̆ıın ortaya çıkmasını engellemektedir (Gül ve Özcan, 2011: 108). Bütün bu faktörler dikkate alındığında, örgüt üyelerinin sessizlik tutumları "iş ortamından", "duygularından", "sessizliğin kaynă̆ından", "yöneticilerinden" ve "izolasyondan" kaynaklı olarak ortaya çıkabilmektedir. İş ortamından kaynaklanan sessizlik, genellikle çalışma ortamı ve koşullarından (işin kendisi, iş arkadaşları, temizlik, havalandırma, 
1şıklandırma, yeterli teçhizat gibi) kaynaklanmaktadır. İşgörenlerin sahip oldukları kişilik özellikleri, ruhsal durumları, bireysel/demografik özellikleri gibi duygularıyla doğrudan ilişkili olan faktörler işgörenlerin duygularından kaynaklı sessizliğine sebep olabileceği söylenebilir. Sessizliğin kaynağı olarak nitelendiren diğer sessizlik faktörleri; çalışanların duygu ve düşüncelerini açıkça ifade edememeleri, örgütteki israf ve kayıplara karşı sessiz kalmaları, kendilerine adil davranılmadıklarını düşünmeleri ve kendilerini işleri ile ilgili yetersiz görmeleri gibi faktörler olarak sayılabilir. İşgörenlerin yöneticilerinden kaynaklanan sessizlik davranışları ise tamamen yöneticilerden kaynaklanan faktörlerdir. İnsanların sosyal olarak kendisini bir gurubun parçası ya da bir gruba ait olmadıklarını hissetmeleri ile ilgili olan izolasyon boyutuyla ilgili olarak ise işgörenler dışlanma, mimlenme gibi endişelerinden kaynaklı olarak sessiz kalmayı tercih edebilmektedir.

Araştırmanın modeline aşağıda yer verilmiştir:

Şekil 1. Araştırma modeli

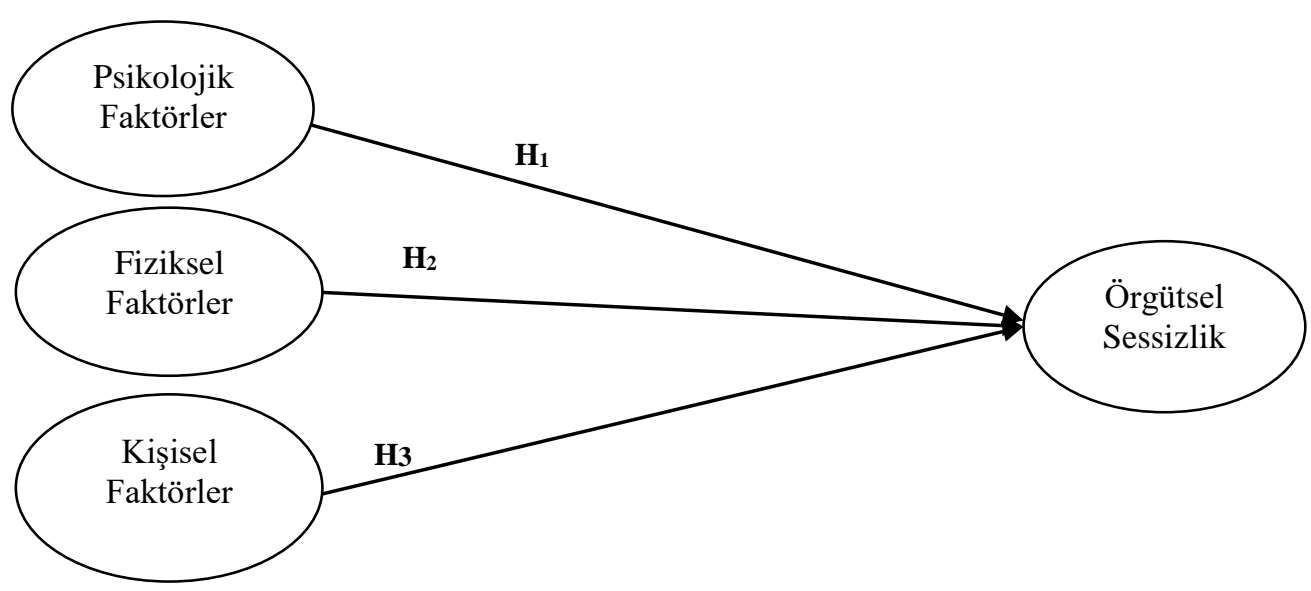

Örgütün varlığını sürdürebilmesi ve rakipleri arasında fark yaratabilmesi için yeni fikir ve görüşlere ihtiyaç duyulmaktadır (Dilek ve Taşkıran, 2016: 403). Bu doğrultuda işgören sessizliğinin önlenmesi, kurumların kıt kaynaklarının daha etkin kullanılabilmesi, daha verimli ve üretken olunabilmesi için önem arz etmektedir (Çakıcı, 2007: 159). Kadın işgörenlerin turizm sektöründeki yeri ve önemi dikkate alındığında, konuyla ilgili yapılmış olan çalışmaların sınırlı olduğu gözlenmiştir. Bu doğrultuda bu araştırmada kadın çalışanların karşılaştıkları sorunların örgütsel sessizlikleri üzerindeki etkisinin belirlenmesi amaçlanmıştır. $\mathrm{Bu}$ amaçla şu hipotezler geliştirilmiştir:

H1: Otel işletmelerinde çalışan kadın işgörenlerin karşılaştığ 1 psikolojik sorunlar, örgütsel sessizliklerini pozitif yönde etkilemektedir.

H2: Otel işletmelerinde çalışan kadın işgörenlerin karşılaştığ1 fiziksel sorunlar, örgütsel sessizliklerini pozitif yönde etkilemektedir.

H3: Otel işletmelerinde çalışan kadın işgörenlerin karşılaştığı kişisel sorunlar, örgütsel sessizliklerini pozitif yönde etkilemektedir. 


\section{Araştırmanın Yöntemi}

Araştırma uygulamalı bir araştırma olup betimsel nitelik taşımaktadır. Araştırmanın evrenini Bodrum İlçesinde bulunan 3, 4 ve 5 yıldızlı otel işletmelerinde çalışan kadın işgörenler oluşturmaktadır. Evrenin tamamına ulaşılması zaman, maliyet ve kontrol güçlüklerinden dolayı zor olduğundan örneklem alma yoluna gidilmiştir. Bu doğrultuda Bodrum'da faaliyet gösteren ve uygun örnekleme yöntemi ile seçilen 3, 4 ve 5 yıldızlı toplam 26 otel işletmesinde çalışan 450 kadın işgörene anket dağıtılmıştır. Geri dönen anketlerden bir kısmının hatalı ve eksik olması sebebiyle elenmesi sonucunda toplam 429 anket araştırma kapsamında değerlendirmeye alınmıştır. Kadın işgörenlere dağıtılan anket üç bölümden oluşmaktadır. Birinci bölümde katılımcıların demografik özelliklerini belirlemeye yönelik 8 ifade (yaş, medeni durum, eğitim durumu, turizm eğitimi alma durumu, sektördeki toplam çalışma süresi, son işletmedeki toplam çalışma süresi, otalama aylık gelir durumu ve çalışılan bölüm) yer almaktadır. İkinci bölümde kadın işgörenlerin karşılaştığı sorunları belirlemeye yönelik Doğan (2012) ile Pelit vd. (2016) tarafından kullanılan 24 ifadeden ve psikolojik, fiziksel ve kişisel olmak üzere 3 boyuttan oluşan ölçekten yararlanılmıştır. Anketin üçüncü bölümünde ise Kahveci ve Demirtaş (2013b) tarafından öğretmenler için geliştirilmiş olan ve 18 ifadeden oluşan "örgütsel sessizlik ölçeği” turizm sektörü ve kadın işgörenler için uyarlanmış ve ölçeğin ikinci ifadesinden ayrı iki ifade (yönetici ve iş arkadaşları) oluşturma yoluyla toplamda 19 ifadeden oluşan örgütsel sessizlik ölçeğinden yararlanılmıştır. Her iki ölçekteki ifadelere ilişkin görüşler, 5'li Likert tipi derecelendirmeye göre tasarlanmıştır.

\section{Bulgular ve Tartışma}

Araştırma kapsamında yapılan analizler doğrultusunda elde edilen bulgular ve bu bulguların yorumlarına bu bölümde ayrıntılı olarak yer verilmektedir.

\subsection{Kadın İşgörenlerin Bireysel Özelliklerine İlişkin Bulgular}

Araştırmanın örneklem grubunu oluşturan toplam 429 kadın işgörenin bireysel özelliklerine ilişkin betimsel istatistik testi yapılmış olup, elde edilen frekans ve yüzde dağılımları Tablo 1'de ayrıntılı olarak sunulmuştur.

Araştırma kapsamında incelenen toplam 429 kadın işgörenin \% 49,0 ile büyük bir çoğunluğunu "23-32 yaş" arasındaki katılımcılar ile \%28,0 oranında "33-42 yaş" arasındaki katılımcılar oluşturmaktadır. Kadın işgörenlerin \%46,4'ü "bekâr", \%49,9'u "evli”" ve \%3,7'si ise "diğer" (boşanmış, nişanlı vb.) kategorisinden oluşan katılımcılardan oluşmaktadır.

Araştırmaya katılan kadınların \%45,5'i “üniversite", \%42,7'si "lise" ve \%11,9'u ise "ortaöğretim" mezunudur. Alanında uzman ve eğitimli kişilerin istihdam edilmesi, her meslek grubu ve sektör türünde olduğu gibi turizm ve otelcilik sektöründe de oldukça önem teşkil eden bir konudur. Kadın işgörenlerin \%49,7'sinin turizm eğitimi almamış olduğu tespit edilmiştir. Diğer taraftan katılımcıların \%21,4'ü lise düzeyinde, \%17,5'I önlisans düzeyinde ve $\% 11,4$ 'ü ise lisans düzeyinde turizm eğitimi almıştır. Kadın işgörenlerin sektördeki toplam çalışma süreleri incelendiğinde, büyük çoğunluğunun $(\% 71,3)$ 0-5 y1ldır turizm 
sektöründe çalıştıkları görülmektedir. Kadın işgörenlerin \%94,4'ünün 0-5 yıldır son çalıştıkları işletmede görev yapıyor olduğu değerlendirilmiştir.

Tablo 1. Kadın işgörenlerin bireysel özelliklerine ilişkin bulgular

\begin{tabular}{|c|c|c|c|c|c|c|c|}
\hline Değişkenler & Gruplar & $\mathbf{f}$ & $\%$ & Değişkenler & Gruplar & $\mathbf{f}$ & $\%$ \\
\hline \multirow{3}{*}{$\begin{array}{l}\text { Medeni } \\
\text { Durum }\end{array}$} & Evli & 214 & 49,9 & \multirow{4}{*}{ Yaş } & 22 yaş ve altı & 61 & 14,2 \\
\hline & Bekar & 199 & 46,4 & & 23-32 yaş arası & 210 & 49,0 \\
\hline & Diğer & 16 & 3,7 & & $33-42$ yaş arası & 120 & 28,0 \\
\hline \multirow{3}{*}{$\begin{array}{l}\text { Eğitim } \\
\text { Durumu }\end{array}$} & Ortaöğretim & 51 & 11,9 & & 43 yaş ve üzeri & 38 & 8,9 \\
\hline & Lise & 183 & 42,7 & \multirow{4}{*}{ Bölüm } & Kat Hizmetleri & 67 & 15,6 \\
\hline & Üniversite & 195 & 45,5 & & Ön-büro & 99 & 23,1 \\
\hline \multirow{4}{*}{$\begin{array}{c}\text { Turizm } \\
\text { Eğitimi } \\
\text { Alma } \\
\text { Durumu }\end{array}$} & Almamış & 213 & 49,7 & & Yiyecek-İçecek & 145 & 33,8 \\
\hline & Lise Düzeyi & 92 & 21,4 & & Diğer & 118 & 27,5 \\
\hline & Önlisans Düzeyi & 75 & 17,5 & \multirow{4}{*}{$\begin{array}{c}\text { Sektördeki } \\
\text { Toplam } \\
\text { Çalışma } \\
\text { Süresi }\end{array}$} & 2 yildan az & 148 & 34,5 \\
\hline & Lisans Düzeyi & 49 & 11,4 & & $2-5$ y1l aras1 & 158 & 36,8 \\
\hline \multirow{6}{*}{$\begin{array}{c}\text { Ortalama } \\
\text { Aylık Geliri } \\
\text { (TL) }\end{array}$} & 1500 ve alt 1 & 162 & 37,8 & & 5-9 y1l aras1 & 82 & 19,1 \\
\hline & $1501-2000$ aras1 & 142 & 33,1 & & 10 yıldan fazla & 41 & 9,6 \\
\hline & $2001-2500$ aras1 & 51 & 11,9 & \multirow{4}{*}{$\begin{array}{c}\text { Son } \\
\text { İşletmedeki } \\
\text { Çalışma } \\
\text { Süresi }\end{array}$} & 2 y1ldan az & 284 & 66,2 \\
\hline & 2501-3000 aras1 & 53 & 12,4 & & $2-5$ y1l arasi & 121 & 28,2 \\
\hline & $3001-3500$ aras1 & 11 & 2,6 & & $5-9$ y1l arası & 20 & 4,7 \\
\hline & 3501 ve üzeri & 10 & 2,3 & & 10 yıldan fazla & 4 & 0,9 \\
\hline TOPLAM & & 429 & 100 & TOPLAM & & 429 & 100 \\
\hline
\end{tabular}

Tablo 1'de görüldüğü üzere, katılımc1ların \%37,8'inin asgari ücret düzeylerinde $1500 \mathrm{TL}$ ve altında, \%33,1'inin de yine benzer oranlarda 1501-2000 TL arasında gelir elde ettiği tespit edilmiştir. Ortalama aylık $1500 \mathrm{TL}$ altında gelir elde eden katılımcıların belirli bir bölümünün ise kısmî zamanlı işgörenler tarafından oluştuğu düşünülmektedir. Araştırmaya dâhil edilmiş olan toplam 429 kadın işgörenin \%33,8'i yiyecek-içecek bölümünde, \%23,1'i önbüro bölümünde, \%15,6's1 ise kat hizmetleri bölümünde istihdam edilmektedir.

\subsection{Kadın İşgörenlerin Karşılaştığı Sorunların Örgütsel Sessizlik Düzeyleri Üzerindeki Etkisine İlişkin Bulgular}

Araştırmanın bu bölümünde, öncelikle kadın işgörenlerin karşılaştıkları sorunlar karşılaştırılmış, ardından örgütsel sessizlik ile ilişkisi ve etkisi incelenmiştir. Kadın işgörenlerin karşılaştıkları sorunların birbirine göre farklılıklarını tespit edebilmek amacıyla gerçekleştirilen ilişkili ölçümler için tek faktörlü varyans analizi sonuçları Tablo 2'de verilmiştir.

Tablo 2'deki bulgulara göre, kadın işgörenlerin karşılaştıkları sorunların boyutlarına ilişkin görüşleri arasında anlamlı bir farklılık olduğu görülmektedir $(F=79,549 ; p<0,001)$. Boyutların ikili olarak çoklu karşılaştırmasına yönelik gerçekleştirilen Bonferroni testi sonuçlarına göre, bütün boyutların birbirinden farklı olduğu tespit edilmiştir. Katılımcıların fiziksel faktörlerden kaynaklı karşılaştığ s sorunların aritmetik ortalaması $\overline{\mathrm{x}}=1,65$ ile psikolojik $(\overline{\mathrm{x}}=1,58)$ ve kişisel $(\overline{\mathrm{x}}=1,37)$ faktörlerden kaynaklı sorunların ortalamasından nispeten daha yüksek hesaplanmıştır. Diğer bir ifadeyle, kadın işgörenlerin daha çok somut sorunlarla (ücret, kapasite üzerinde iş yapma, ağır işlerde çalıştırılma ve işyeri koşulları gibi) karşılaştığı yorumu yapılabilir. Benzer bir şekilde, Oaxaca (1973) kentsel işgücü ile ilgili yaptığı çalışmada kadınların erkeklere oranla daha az ücret aldığını; Pelit vd. (2016) 
kadınların turizm sektöründe çoğu zaman kapasitelerinin üzerinde iş yapmak zorunda kaldıklarını ve Maqsood vd. (2005) ise Pakistan'da farklı sektörlerde çalışan kadınların uygun olmayan çalışma koşullarından kaynaklanan sorunlarla karşılaştı̆̆ını belirtmiştir. Bununla birlikte fiziksel sorunlar diğer sorunlara nazaran yüksek olsa da genel olarak karşılaşılan sorunlara ilişkin ortalamaların düşük seviyede olduğu göze çarpmaktadır. Kadın işgörenlerin karşılaştı̆̆1 sorunlarla ilgili yapılan birçok araştırma sonucunda (Gutek ve Morash, 1982; Fitzgerald vd., 1997; Bebekoğlu ve Wasti, 2002; Kocacık ve Gökkaya, 2005; Kocacık ve Ayan, 2011 gibi) önemli bir sorun niteliğinde ön plana çıkmış olan ve psikolojik sorunlar kapsamında ele alınan cinsel taciz sorunsalı, bu çalışmada ise çok az karşılaşılan bir sorun olarak ortaya çıkmıştır.

Tablo 2. Kadın işgörenlerin karşılaştığı sorunların karşılaştırılması

\begin{tabular}{lccccc}
\hline \multicolumn{1}{c}{ Boyutlar } & $\overline{\mathrm{X}}$ & S.s & F & $\mathbf{p}$ & $\begin{array}{c}\text { Çoklu } \\
\text { karşılaştırma }\end{array}$ \\
\hline Psikolojik Sorunlar & 1,58 & 0,65 & & & $\mathrm{a}$ \\
Fiziksel Sorunlar & 1,65 & 0,57 & 79,549 & $\mathbf{0 , 0 0 0 *}$ & $\mathrm{b}$ \\
Kişisel Sorunlar & 1,37 & 0,54 & & & $\mathrm{c}$ \\
\hline
\end{tabular}

* $p<0,001 \quad a, b$ : farklı harfleri içeren boyutlar arasında anlaml farklllık vardır $(p<0,05)$.

Kadın işgörenlerin karşılaştı̆g sorunlar ile örgütsel sessizlik düzeyleri arasındaki ilişkiyi belirlemek amacıyla korelasyon analizi yapılmış ve analiz sonuçları Tablo 3 'te verilmiştir. Yapılan korelasyon analizinde, kadın işgörenlerin karşılaştığ 1 sorunlar ve alt boyutları bağımsız değişken; örgütsel sessizlik ve alt boyutları ise bağımlı değişken olarak analize tabi tutulmuştur.

Tablo 3. Değişkenlere ait ortalama, standart sapma ve korelasyon değerleri

\begin{tabular}{ccccccc}
\hline & $\bar{X}$ & s.s & $\mathbf{1}$ & $\mathbf{2}$ & $\mathbf{3}$ & $\mathbf{4}$ \\
\hline Psikolojik Faktörler & 1,58 & 0,65 & $(0,865)$ & $0,703^{* *}$ & $0,617^{* *}$ & $0,743^{* *}$ \\
\hline Fiziksel Faktörler & 1,65 & 0,57 & $0,703^{* *}$ & $(0,761)$ & $0,645^{* *}$ & $0,722^{* *}$ \\
\hline Kişisel Faktörler & 1,36 & 0,64 & $0,617^{* *}$ & $0,645^{* *}$ & $(0,801)$ & $0,635^{* *}$ \\
\hline Örgütsel Sessizlik & 1,97 & 0,75 & $0,743^{* *}$ & $0,722^{* *}$ & $0,635^{* *}$ & $(0,938)$ \\
\hline
\end{tabular}

$p<0,05, * * p<0,01$, Parantez içerindeki değerler, ölçeklerin Cronbach Alfa Katsayılarıdır.

Tablo 3’teki sonuçlar incelendiğinde, kadın işgörenlerin karşılaştığı sorunlar ve alt boyutları ile örgütsel sessizlik düzeyleri arasında 0,001 anlamlılık düzeyinde anlamlı ilişkiler $(\mathrm{p}=0,000<0,001)$ olduğu anlaşılmaktadır. Buna göre, kadın işgörenlerin karşılaş̧ığı psikolojik faktörlerden kaynaklı sorunlar ile örgütsel sessizliğin $(r=0,743)$ ile pozitif yönlü ve yüksek kuvvette; fiziksel faktörlerden kaynaklı sorunlar $(\mathrm{r}=0,722)$ ile pozitif yönlü ve yüksek kuvvette; kişisel faktörlerden kaynaklı sorunlar ile ise $(\mathrm{r}=0,635)$ ile pozitif yönlü ve orta kuvvette ilişkiler saptanmıştır. Kadın işgörenlerin karşılaştığı sorunların hangi faktörlerden kaynaklandığını gösteren alt boyutları ile örgütsel sessizlik düzeyleri arasındaki ilişki/etkinin matematiksel bir modelle açıklanması amacıyla gerçekleştirilen basit doğrusal regresyon analizleri aşağıda sunulmuştur. 
Tablo 4. İşyerinde karşılaşılan psikolojik boyuttaki sorunların Örgütsel Sessizlik Üzerindeki Etkisine İlişkin Basit Doğrusal Regresyon Analizi Sonucu

\begin{tabular}{|c|c|c|c|c|c|c|c|}
\hline $\begin{array}{c}\text { Bağımlı } \\
\text { Değişken }\end{array}$ & $\begin{array}{c}\text { Bağımsız } \\
\text { Değişkenler }\end{array}$ & $b_{j}$ & $S\left(b_{j}\right)$ & $\mathrm{t}$ & $\mathrm{p}$ & $\mathrm{R}^{2}$ & ANOVA \\
\hline & Sabit & 0,603 & 0,065 & 9,334 & $0,000^{* * * *}$ & \multirow[b]{2}{*}{0,550} & \multirow{2}{*}{$\begin{array}{l}\mathrm{F}=524,788 \\
\mathrm{p}=0,000^{* * *}\end{array}$} \\
\hline Sessizlik & $\begin{array}{c}\text { Psikolojik } \\
\text { Faktörler }\end{array}$ & 0,864 & 0,038 & 22,908 & $0,000 * * *$ & & \\
\hline
\end{tabular}

${ }^{* *} p<0,01 * * * p<0,001$ bj: Katsayl S(bj): Standart Hata

Tablo 4'teki bulgulara göre, bağımlı değişken (örgütsel sessizlik) ile bağımsız değişken (psikolojik faktörler) arasındaki ilişkiye ait basit doğrusal regresyon modeli şu şekilde verilebilir: Örgütsel Sessizlik $=0,603+0,864 \mathrm{PF}$

Tablo 4, psikolojik faktörlerin örgütsel sessizlik üzerindeki etkisini belirlemeye yönelik gerçekleştirilen basit doğrusal regresyon modelinin anlamlı olduğunu göstermektedir $(\mathrm{F}=524,788 ; \mathrm{p}<0,001)$. Tablo 4'teki belirtme katsayısına göre ( $\mathrm{R} 2)$, kadın işgörenlerin Örgütsel sessizlikleri üzerindeki değişimlerin \%55'inin (R2=0,550) psikolojik faktörlerden kaynaklandığ1 anlaşılmaktadır. Buna göre; "H1: Otel işletmelerinde çalışan kadın işgörenlerin karşılaştı̆̆ı psikolojik sorunlar, örgütsel sessizliklerini pozitif yönde etkilemektedir" hipotezi desteklenmiştir.

Tablo 5. İşyerinde karşılaşılan fiziksel boyuttaki sorunların örgütsel sessizlik üzerindeki etkisine ilişkin basit doğrusal regresyon analizi sonucu

\begin{tabular}{cccccccc}
\hline $\begin{array}{c}\text { Bağımlı } \\
\text { Değişken }\end{array}$ & $\begin{array}{c}\text { Bağımsız } \\
\text { Değişkenler }\end{array}$ & $\mathrm{b}_{\mathrm{j}}$ & $\mathrm{S}\left(\mathrm{b}_{\mathrm{j}}\right)$ & $\mathrm{t}$ & $\mathrm{p}$ & $\mathrm{R}^{2}$ & ANOVA \\
\hline Örgütsel & Sabit & 0,407 & 0,077 & 5,304 & $0,000^{* * *}$ & \multirow{2}{*}{0,521} & $\mathrm{~F}=466,040$ \\
Sessizlik & Fiziksel Faktörler & 0,947 & 0,044 & 21,588 & $0,000^{* * * *}$ & & $\mathrm{p}=0,000^{* * *}$ \\
\hline
\end{tabular}

${ }^{* *} p<0,01 * * * p<0,001 \quad$ bj: Katsayl $S(b j):$ Standart Hata

Tablo 5'teki bulgulara göre, bağımlı değişken (örgütsel sessizlik) ile bağımsız değişken (fiziksel faktörler) arasındaki ilişkiye ait basit doğrusal regresyon modeli şu şekilde verilebilir: Örgütsel Sessizlik $=0,407+0,947$ FF

Tablo 5, fiziksel faktörlerin örgütsel sessizlik üzerindeki etkisini belirlemeye yönelik gerçekleştirilen basit doğrusal regresyon modelinin anlamlı olduğunu göstermektedir $(\mathrm{F}=466,040 ; \mathrm{p}<0,001)$. Tablo 5'teki belirtme katsayısına göre $\left(\mathrm{R}^{2}\right)$, kadın işgörenlerin Örgütsel sessizlikleri üzerindeki değişimlerin $\% 52,1$ 'inin $\left(\mathrm{R}^{2}=0,521\right)$ fiziksel faktörlerden kaynaklandığ1 anlaşılmaktadır. Buna göre; "H2: Otel işletmelerinde çalışan kadın işgörenlerin karşılaştı̆̆ fiziksel sorunlar, örgütsel sessizliklerini pozitif yönde etkilemektedir" hipotezi desteklenmiştir. 
Tablo 6. İşyerinde karşılaşılan kişisel boyuttaki sorunların örgütsel sessizlik üzerindeki etkisine ilişkin basit doğrusal regresyon analizi sonucu

\begin{tabular}{|c|c|c|c|c|c|c|c|}
\hline $\begin{array}{c}\text { Bağımlı } \\
\text { Değişken }\end{array}$ & $\begin{array}{c}\text { Bağımsız } \\
\text { Değişkenler }\end{array}$ & $\mathbf{b}_{\mathbf{j}}$ & $\mathbf{S}\left(\mathbf{b}_{\mathbf{j}}\right)$ & $\mathbf{t}$ & $\mathbf{p}$ & $\mathbf{R}^{2}$ & ANOVA \\
\hline \multirow{2}{*}{$\begin{array}{l}\text { Örgütsel } \\
\text { Sessizlik }\end{array}$} & Sabit & 0,761 & 0,077 & 9,926 & $0,000 * * *$ & \multirow[b]{2}{*}{0,402} & \multirow{2}{*}{$\begin{array}{l}\mathrm{F}=288,263 \\
\mathrm{p}=0,000^{* *}\end{array}$} \\
\hline & $\begin{array}{c}\text { Kişisel } \\
\text { Faktörler }\end{array}$ & 0,887 & 0,052 & 16,978 & $0,000 * * *$ & & \\
\hline
\end{tabular}

**p $<0,01 \quad * * * \mathrm{p}<0,001 \quad$ bj: Katsay1 S(bj): Standart Hata

Tablo 6'daki bulgulara göre, bağımlı değişken (örgütsel sessizlik) ile bağımsız değişken (kişisel faktörler) arasındaki ilişkiye ait basit doğrusal regresyon modeli şu şekilde verilebilir: Örgütsel Sessizlik $=0,761+0,887 \mathrm{KF}$

Şekil 2. Araştırma Modeli Üzerinde Regresyon Analizleri Sonuçlarının Görünümü

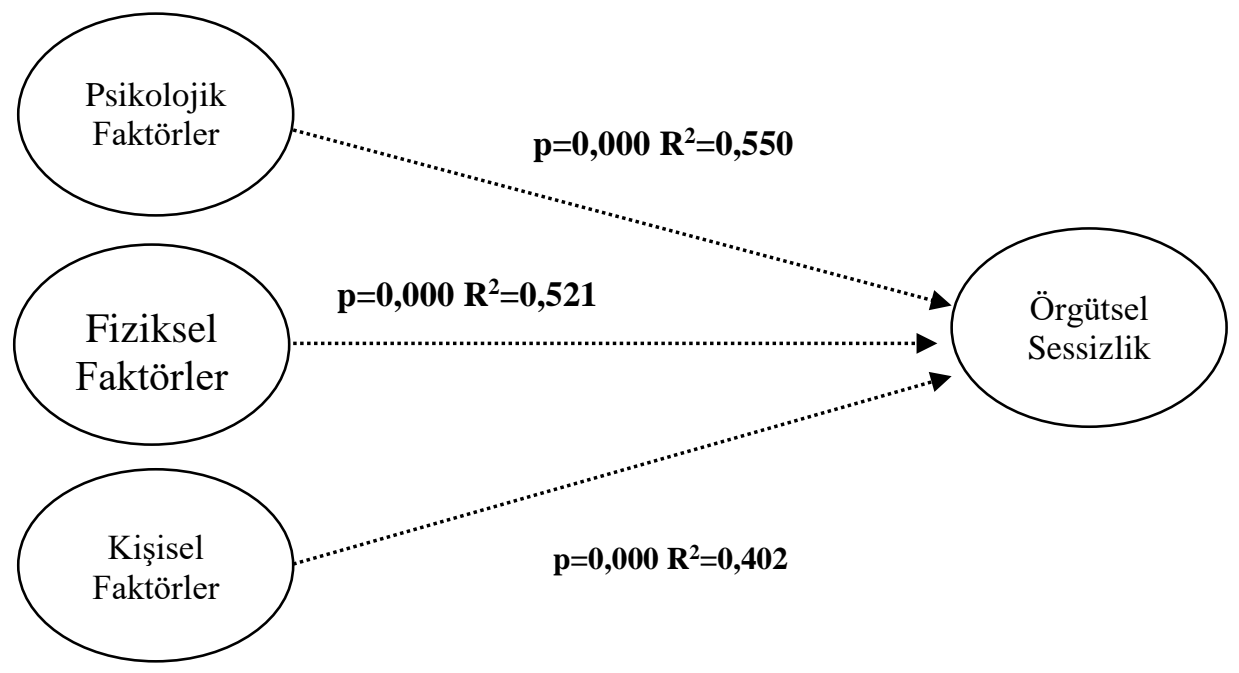

Tablo 6, kişisel faktörlerin örgütsel sessizlik üzerindeki etkisini belirlemeye yönelik gerçekleştirilen basit doğrusal regresyon modelinin anlamlı olduğunu göstermektedir $(\mathrm{F}=288,263 ; \mathrm{p}<0,001)$. Tablo 6'daki belirtme katsayısına göre $\left(\mathrm{R}^{2}\right)$, kadın işgörenlerin Örgütsel sessizlikleri üzerindeki değişimlerin $\% 40,2$ 'sinin $\left(\mathrm{R}^{2}=0,402\right)$ kişisel faktörlerden kaynaklandığ1 anlaşılmaktadır. Buna göre; "H3: Otel işletmelerinde çalışan kadın işgörenlerin karşılaştı̆̆ kişisel sorunlar, örgütsel sessizliklerini pozitif yönde etkilemektedir" hipotezi de desteklenmiş olmaktadır.

\section{Sonuç ve Öneriler}

Araştırma kapsamında yapılan analiz sonuçları dikkate alındığında, kadın işgörenlerin işyerinde karşılaştığı sorunların örgütsel sessizlik düzeyleri üzerinde etkili olduğu tespit edilmiştir. Kadın işgörenlerin karşılaştığ gösterdikleri örgütsel sessizlik davranışı hem bireyin kendisini hem de örgütü önemli ölçüde olumsuz yönde etkileyebilecek olan örgütsel sorun niteliği taşımaktadır. İşgörenlerin bu tür sorunlarla karşı karşıya kalması, zamanla mutsuz bireyler haline gelmelerine, böylelikle düşük motivasyon ve düşük tatmin ile düşük verimlilik ve düşük performans sergilemelerine 
neden olabilir. Bu noktada, işletme yöneticileri örgütün sağlığını ve varlığını sürdürebilmesi amacıyla, işgörenlerin karşılaştığı sorunları ve bu sorunların kaynağını iyi analiz etmeli ve örgütsel sessizliği ortadan kaldırmaya ya da en az düzeye indirmeye yönelik duygu ve düşüncelerini ifade etmeleri konusunda işgörenleri cesaretlendirmelidir.

Gerek kadın işgörenlerin karşılaştığı sorunlarla gerekse örgütsel sessizlik sorunsalı ile ilgili yapılan bazı çalışmaların sonuçları ile otel işletmelerinde çalışan kadın işgörenlerin karşılaştığı sorunlar ve örgütsel sessizlik düzeyleri üzerine yapılan bu çalışmanın sonuçları arasında benzerlikler olduğu görülmüştür. Örneğin, Demirkol vd. (2004) tarafından turizm sektöründe çalışan kadınların sorunlarıyla ilgili 209 kadın ile gerçekleştirilen çalışmada "iş yükü ve çalışma sürelerinin fazlalığı", "sorumluluk verilmesine karşın yetkinin azlığı", "sendikal hakkın fazla yaygın olmadığı", "hizmet içi eğitim olanağı yetersizlikleri", "iş güvencesi, ücret, rotasyon uygulama imkânları yetersizlikleri”, "taciz" gibi sorunların daha fazla ön planda olduğu sonucuna ulaşılmıştır. Anafarta vd. (2008)'nin konaklama işletmelerinde kadın yöneticilerin cam tavan algısını ölçmeye yönelik 151 kadın yönetici ile gerçekleştirdiği çalışmada kadınların "sırf cinsiyetten dolayı örgütte yükselememesi" ve "ücret ayrımcıllğı" gibi sorunlarla karşılaştıkları belirtilmiştir. Benzer bir şekilde Yılmaz vd. (2008)'nin kamu örgütlerinde çalışan kadınların sorunlarına ilişkin 120 kadın çalışan ile yaptıkları çalışmada "yönetimsel tutumların iyi olmayışı", "cinsiyet ayrımcılığı", "işten kaynaklı meslek hastalıkları yaşamak" gibi sorunlar yaşandığı tespit edilmiştir. Soysal (2010) tarafından kadın girişimcilerin karşılaştı̆̆ 1 sorunlar üzerine 60 kadın ile gerçekleştirilen çalışmanın sonucunda ise en fazla "toplumun geleneksel bakış açısı ve algısı" sorunsalı ile karşılaşıldığı vurgulanmıştır. Bu çalışmaya oranla biraz daha farklı bulgulara sahip olan Avais vd. (2014), Pakistan Sukkur'da kadın çalışanların sorunlarına ilişkin 150 kadın çalışan ile gerçekleştirdiği çalışmada en fazla "cinsel taciz" ve "aileye yeterli zaman ayıramama" sorunlarının olduğunu belirtilmiştir. Bunun sebebi ise ülkelerin gelişmişlik düzeyi ve sahip olduğu kültürel yapı ile açılanabilir. Kadın çalışanların örgütsel sessizlik davranışlarıyla ilgili olarak Bayın vd. (2015)'nin hemşirelerde örgütsel sessizlik nedenlerinin belirlenmesine yönelik 237 hemşire üzerinde yaptıkları çalışmada da benzer bir şekilde en fazla "yönetsel ve örgütsel" nedenlerden dolayı sessiz kalma davranışı gösterdikleri sonucuna ulaşılmıştır.

Sonuç olarak, kaynağı ne olursa olsun kadın işgörenlerin karşılaşmış olduğu sorunlar ve bazı nedenlerden kaynaklı olarak örgüt içinde örgütle ilgili duygu ve düşüncelerini ifade edememeleri olarak bilinen örgütsel sessizlik davranışı sergilemeleri zamanla örgütün sağlığını ve verimliliğini olumsuz yönde etkileyebilecektir. Böylesine önemli örgütsel sorun niteliğinde olan kadın işgörenlerin karşılaştı̆̆ 1 sorunlar ve örgütsel sessizlik davranışlarına ilişkin elde edilen bulgular ve sonuçlar doğrultusunda konuyla ilgili birtakım öneriler geliştirilmiştir:

- Öncelikle kadın işgörenlerin örgütsel sessizlik davranışı sergilemelerinin önüne geçilebilmesi adına işleriyle ilgili duygu ve düşüncelerini ifade edebilmeleri için cesaretlendirilmeli ve örgütsel kararlara katılımları sağlanmalıdır.

- Kadın işgörenlerin karşılaştı̆̆ sorunların daha net belirlenebilmesi amaciyla düzenli olarak haftalık personel toplantıları yapılabilir, birebir iletişim gerektiren özel konular için toplantı sonrasında 1-2 saatlik görüşmelerin ayarlanması fayda sağlayabilir. 
- Çalışmada tespit edilmiş olan önemli sorunlardan bir diğeri kadın işgörenlerin aldıkları ücreti yetersiz bulmalarıdır. Kadın ve erkek işgörenler arasında cinsiyet ayrımcılığı yapılmadan eşit ücret ve eşit terfi/yükselme imkânlarının sunulması işgörenlerin motivasyonunu ve tatminini artırmada etkin bir rol oynayabilecektir.

- Örgüt içinde örgüt üyeleri arasında etkili bir iletişim ağının oluşturulması, işgörenlerin örgüte olan bağlılı̆̆ını artıracak ve işgörenlerin kendilerini daha iyi ifade etmelerine olanak sağlayacaktır.

- Yöneticiler, işgörenler arasındaki iş dağılımını iyi planlamalı ve çalışanlar kapasitelerinin üzerinde iş yapmaları için zor durumda bırakılmamalıdır. Çünkü yoğun bir tempo gerektiren otel işletmelerinde yapılan ve yapılacak işler günlük olarak düşünülmemeli, haftalık, aylık ve sezonluk olarak planlar yapılmalıdır.

- Bu araştırma deniz-kum-güneş turizminin yoğun yaşandığ popüler bir destinasyon olan Bodrum İlçesinde gerçekleştirilmiştir. Ancak, farklı faktörlerden (kültürel yapı, toplum yapısı, kadın çalışanlara bakış açısı gibi) kaynaklı olarak kadın işgörenlerin karşılaştığı sorunlar ve örgütsel sessizlik davranış düzeyleri sayfiye otel işletmelerinde ve şehir otel işletmelerinde farklılık gösterebileceği düşünülmektedir. Aynı çalışma şehir otellerinde çalışan kadın işgörenler üzerinde gerçekleştirilebilir ve sonuçlar karşılaştırılabilir.

\section{Kaynakça}

Acaray, A., Gündüz Çekmecelioğlu, H. ve Akturan, A. (2015). "Örgüt Kültürü ile Örgütsel Sessizlik Arasındaki İlişkinin İncelenmesi”, International Journal of Social Science, 2015(32):139-157.

Aktaş, H. ve Şimşek, E. (2014). "Örgütsel Sessizlik İle Algılanan Bireysel Performans, Örgüt Kültürü Ve Demografik Değişkenler Arasındaki Etkileşim”, Akdeniz Üniversitesi İktisadi ve İdari Bilimler Fakültesi Dergisi, 2014(28):24-52.

Algın, İ. (2014). Üniversitelerde Örgütsel Sessizlik, Hacettepe Üniversitesi Eğitim Bilimleri Enstitüsü, Yüksek Lisans Tezi, Ankara.

Alparslan, A. M. ve Kayalar, M. (2012). "Örgütsel Sessizlik: Sessizlik Davranışları ve Örgütsel ve Bireysel Etkileri”, Mehmet Akif Ersoy Üniversitesi Sosyal Bilimler Enstitüsü Dergisi, 4(6):136-147.

Alparslan, A. M., Çetinkaya Bozkurt, Ö. ve Özgöz, A. (2015). "İşletmelerde Cinsiyet Ayrımcılığı ve Kadın Çalışanların Sorunları”, MAKÜ İktisadi ve İdari Bilimler Fakültesi Dergisi, 2(3):66-81.

Altok, T. (2009). Çalışanların Motivasyonunu Etkileyen Faktörlere İlişkin Hizmet ve İmalat İşletmelerinde Karşılaştırmalı Bir Araştırma, Süleyman Demirel Üniversitesi Sosyal Bilimler Enstitüsü, Yüksek Lisans Tezi, Isparta.

Amah, O. E., and Okafor, C. A. (2008). "Relationships Among Silence Climate, Employee Silence Behavior and Work Attitudes: The Role of Self-Esteem and Locus of Control", Asian Journal of Scientific Research, 1(1):1-11.

Anafarta, N., Sarvan, F. ve Yapıcı, N. (2008). "Konaklama İşletmelerinde Kadın Yöneticilerin Cam Tavan Algısı: Antalya İlinde Bir Araştırma", Akdeniz İ.İ.B.F. Dergisi, 2008(15):111-137.

Arlı, D. (2013). "İlkokul Müdürlerinin Örgütsel Sessizlik İle İlgili Görüşleri”, Trakya Üniversitesi Eğitim Fakültesi Dergisi, 3(2):69-84. 
Avais, M. A.; Wassan, A. A. and Shah, S. (2014). "A Case Study on Problems of Working Women in City Sukkur" Academic Research International, 5(2):325-333.

Aydın Tükeltürk, Ş. ve Perçin Şahin, N. (2008). "Turizm Sektöründe Kadın Çalışanların Karşılaştıkları Kariyer Engelleri ve Cam Tavan Sendromu: Cam Tavanı Kırmaya Yönelik Stratejiler", Yönetim Bilimleri Dergisi, 6(2):113-128.

Ayvaz Kızılgöl, Ö. (2012). "Kadınların İşücüne Katılımının Belirleyicileri: Ekonometrik Bir Analiz", Doğuş University Journal, 13(1):88-101.

Bayın, G., Yeşilaydın, G. ve Esatoğlu, A. E. (2015). "Hemşirelerde Örgütsel Sessizlik Nedenlerinin Belirlenmesi”, İşletme Araştırmaları Dergisi, 7(1):248-266.

Bryant, M. and Wolfram Cox, J. (2004). "Conversion Stories as Shifting Narratives of Organizational Change", Journal of Organizational Change Management, 17(6):578-592.

Bebekoğlu, G. ve Wasti, S. A. (2002). "Çalışan Kadınlara Yönelik Cinsiyet Temelli Düşmanca Davranışların Sebepleri ve Sonuçları Üzerine Bir Araştırma", Yönetim Araştırmaları Dergisi, 2(2):1-40.

Cam, E. (2004). "Çalışma Yaşamında Stres ve Kamu Kesiminde Kadın Çalışanlar", Uluslararas1 İnsan Bilimleri Dergisi, 1(1):1-10.

Çakıcı, A. (2007). “Örgütlerde Sessizlik: Sessizliğin Teorik Temelleri ve Dinamikleri”, Ç. Ü. Sosyal Bilimler Enstitüsü Dergisi, 16(1):145-162.

Çakı̈, Ö. (2008). "Türkiye'de Kadının Çalışma Yaşamından Dışlanması", Erciyes Üniversitesi İktisadi ve İdari Bilimler Fakültesi Dergisi, 2008(31):25-47.

Çavuş, M. F., Develi, A. ve Sarığlu, G. S. (2015). "Mobbing ve Örgütsel Sessizlik: Enerji Sektörü Çalışanları Üzerine Bir Araştırma”, İşletme ve İktisat Çalışmaları Dergisi, 3(1):10-20.

Dalkıranoğlu, T. ve Çetinel, F. G. (2008). "Konaklama İşletmelerinde Kadın ve Erkek Yöneticilerin Cinsiyet Ayrımcılığına Karşı Tutumlarının Karşılaştırılması”, Dumlupınar Üniversitesi Sosyal Bilimler Dergisi, 2008(20):277-298.

Demir, M. (2014). "İşgörenlerin Adalet Algılamaları Kapsamında Sessizlik Davranışının Kariyer Beklentisi ile İlişkisi”, International Journal of Human Science, 11(1):1095-1113.

Demirel, R. (1989). Yaş, Cinsiyet ve Mesleki Deneyimin Üniversite Kütüphanelerinde Çalışan Kütüphanecilerin İş Tatminine Etkisi, Hacettepe Üniversitesi Sosyal Bilimler Enstitüsü, Yüksek Lisans Tezi, Ankara.

Demirkol, Ş., Fidan, F. ve Pelit, E. (2004). "Turizm Sektöründeki Bayan İşgörenlerin Karşılaştıkları Sorunlar ve Otel İşletmelerinde Bir Uygulama", Abant İzzet Baysal Üniversitesi Sosyal Bilimler Enstitüsü Dergisi, 1(8):71-88.

Dilek, Y. ve Taşkıran, E. (2016). "Kişilik Özelliklerinin Örgütsel Sessizlik Üzerindeki Etkisini Belirlemeye Yönelik Bir Araştırma", Bartın Üniversitesi İktisadi ve İdari Bilimler Fakültesi Dergisi, 7(13):402-434.

Doğan, İ. (2012). İşyerinde Psikolojik Taciz ve Yıldırmanın İşten Ayrılmalar Üzerine Etkisi: Bankacılık Sektöründe Bir İnceleme, Çağ Üniversitesi Sosyal Bilimler Enstitüsü, Yüksek Lisans Tezi, Adana.

Dönmez, E. (2016). Örgütsel Sosyalleşme İle Örgütsel Sessizlik Arasındaki İlişki, Pamukkale Üniversitesi Eğitim Bilimleri Enstitüsü, Yüksek Lisans Tezi, Denizli.

Eroğlu, A. H., Adıgüzel, O. ve Öztürk, U. C. (2011). "Sessizlik Gidabı ve Bağlılık İkilemi: İsgören Sessizliği ile Örgütsel Bağlılık İlişkisi ve Bir Araştırma", Süleyman Demirel Üniversitesi İktisadi ve İdari Bilimler Fakültesi Dergisi, 16(2):97-124.

Erol, G. ve Köroğlu, A. (2013). "Liderlik Tarzları ve Örgütsel Sessizlik İlişkisi: Otel İşletmelerinde Bir Araştırma", Seyahat ve Otel İşletmeciliği Dergisi, 10(3):45-64. 
Fitzgerald, L. F., Drasgow, F., Hulin C. L., Gelfand, M. J. and Magley, V. J. (1997). "Antecedents and Consequences of Sexual Harassment in Organizations: A Test of An Integrated Model", Journal of Applied Psychology, 82(4):578-589.

Greenberg, J. and Baron, R. A. (2003). "Behavior in Organization: Understanding and Managing the Human Side of Organization", (8th Edition). New Jersey, USA.

Gutek, B. A. and Morash, B. (1982). "Sex-Ratios, Sex-Role Spillover, and Sexual Harassment of Women at Work", Journal of Social Issues, 38(4):55-74.

Gül, H. ve Özcan, N. (2011). "Mobbing ve Örgütsel Sessizlik Arasındaki İlişkiler: Karaman İl Özel İdaresinde Görgül Bir Çalışma”, Kahramanmaraş Sütçü İmam Üniversitesi İktisadi ve İdari Bilimler Fakültesi Dergisi, 1(2):80-134.

Gül, H., Yalçınoğlu, N. ve Atlı, C. Z. (2014). "Türkiye'de Çalışma Yaşamında Kadının Konumu ve Sorunları", TAF Preventive Medicine Bulletin, 13(2):169-176.

ILO (2016). Women at work. http://www.ilo.org/wcmsp5/groups/public/---dgreports/--dcomm/---publ/documents/publication/wcms_457086.pdf (15.07.2017)

Kahraman, S. (2010). "Kadınların Toplumsal Cinsiyet Eşitsizliğine Yönelik Görüşlerinin Belirlenmesi”, Dokuz Eylül Üniversitesi Hemşirelik Yüksekokulu Elektronik Dergisi, 3(1):30-35.

Kahveci, G. ve Demirtaş, Z. (2013a). "Okul Yöneticisi ve Öğretmenlerin Örgütsel Sessizlik Algiları”, Eğitim ve Bilim, 38(167):50-64.

Kahveci, G. ve Demirtaş, Z. (2013b). "Öğretmenler İçin Örgütsel Sessizlik Ölçeği Geliştirme Çalışması", Elektronik Sosyal Bilimler Dergisi, 12(43):167-182.

Karabıyık, İ. (2012). "Türkiye'de Çalışma Hayatında Kadın İstihdamı", Marmara Üniversitesi İ.İ.B.F. Dergisi, 32(1):231-260.

Kılıç, G., Tunç, T., Saraçlı, S. ve Kılıç, İ. (2013). "Örgütsel Stresin Örgütsel Sessizlik Üzerine Etkisi: Beş Yıldızlı Termal Otel İşletmelerinde Bir Uygulama", İşletme Araştırmaları Dergisi, 5(1):17-32.

Kocacık, F. ve Gökkaya, V. B. (2005). "Türkiye'de Çalışan Kadınlar ve Sorunları", Cumhuriyet Üniversitesi İktisadi ve İdari Bilimler Dergisi, 6(1):195-219.

Kocacık, F. ve Ayan, S. (2011). "Türkiye'de Tekstil Alanında Çalışan Kadınlar ve Sorunları: (İstanbul-Adana-Denizli-Sivas ve Tekirdağ İli Örnekleri)", Uluslararası İnsan Bilimleri Dergisi, 8(1):464-483.

Koray, M. (1992). "Çalışma Yaşamında Kadın Gerçekleri”, Amme İdaresi Dergisi, 25(1):93122.

Korkmaz, A. ve Korkut, G. (2012). “Türkiye'de Kadının İşgücüne Katılımının Belirleyicileri”, Süleyman Demirel Üniversitesi İktisadi ve İdari Bilimler Fakültesi Dergisi, 17(2):41-65.

Kuşluvan, Z. ve Kuşluvan, S. (2005). "Otel İşletmelerinde İş ve İşletme İle İlgili Faktörlerin İşgören Tatmini Üzerindeki Görece Etkisi: Nevşehir Örneği”, Anatolia: Turizm Araştırmaları Dergisi, 16(2):183-203.

Kuzgun, Y. ve Sevim, S. A. (2004). "Kadınların Çalışmasına Karşı Tutum ve Dini Yönelim Arasındaki İlişki”, Ankara Üniversitesi Eğitim Bilimleri Fakültesi Dergisi, 37(1):14-27.

Küçük, M. (2015). "Çalışma Hayatında Kadınlar ve Karşılaştıkları Sorunlar: Bir İşverene Bağlı Olarak Çalışan Emekçi Kadınlara İlişkin Bir Araştırma”, Ekonomi Bilimleri Dergisi, 7(1):1-17.

Maqsood, R., CH, B.; Zia, Q. and Cheema, A. (2005). "Problems of Employed Women at Faisalabad-Pakistan”, Journal of Agriculture and Social Sciences, 1(3):245-247. 
Mittal, S., Sharma, S. and Srivastava, P. (2015). "Challenges Faced by Working Women at Workplace, Family and Society- Its Major Issues, Impact and Remedial Measures", International Journal of Research in Social Sciences and Humanities, 5(2):64-77.

Morrison, E. W. and Milliken, F. J. (2000). "Organizational Silence: A Barrier to Change and Development in a Pluralistic World", Academy of Management Review, 25(4):706725 .

Nawaz, M. A., Afzal, N. and Shehzadi, K. (2013). "Problems of Formally Employed Women: A Case Study of Bahawalnagar, Pakistan", Asian Journal of Empirical Research, 3(10):1291-1299.

Noelle-Neumann, E. (1974). "The Spiral of Silence, A Theory of Public Opinion", Journal of Communication, 24(2):43-51.

Oaxaca, R. (1973). "Male-Female Wage Differentials in Urban Labor Markets", International Economic Review, 14(3):693-709.

Önal, S. (2015). Örgütsel Sessizlik Yabancılaşma İlişkisi: Çanakkale'deki Orta ve Büyük Ölçekli Oteller Üzerine Bir Araştırma, Trakya Üniversitesi Sosyal Bilimler Enstitüsü Yüksek Lisans Tezi, Edirne.

Örücü, E., Kılıç, R. ve Kılıç, T. (2007). "Cam Tavan Sendromu ve Kadınların Üst Düzey Yönetici Pozisyonuna Yükselmelerindeki Engeller: Balıkesir İli Örneği”, Yönetim ve Ekonomi, 14(2):117-135.

Özçatal, E. Ö. (2011). "Ataerkillik, Toplumsal Cinsiyet ve Kadının Çalışma Yaşamına Katılımı", Çankırı Karatekin Üniversitesi İktisadi ve İdari Bilimler Fakültesi Dergisi, $1(1): 21-39$.

Parlaktuna, İ. (2010). “Türkiye'de Cinsiyete Dayalı Mesleki Ayrımcılığın Analizi”, Ege Akademik Bakış, 10(4):1217-1230.

Pelit, E., Güçer, E. ve Demirdağ, Ş. A. (2016). "Kadın İşgörenlerin Karşılaştığı Sorunların İş Bırakma Eğilimlerine Etkisi: Otel İşletmelerinde Bir Araştırma", Mehmet Akif Ersoy Üniversitesi Sosyal Bilimler Enstitüsü Dergisi, 8(15):43-65.

Premeaux, S. F. and Bedeian, A. G. (2003). "Breaking the Silence: The Moderating Effects of Self-Monitoring in Predicting Speaking Up in the Workplace", Journal of Management Studies, 40(6): 1537-1562.

Sayın, E. (2011). "Kadın Girişimcilerin Sorunlarının Betimleyici Analizi”, Organizasyon ve Yönetim Bilimleri Dergisi, 3(1):23-32.

Soysal, A. (2010). "Kadın Girişimcilerin Özellikleri, Karşılaştıkları Sorunlar ve İş Kuracak Kadınlara Öneriler: Kahramanmaraş İlinde Bir Araştırma", Eskişehir Osmangazi Üniversitesi İ.İ.B.F. Dergisi, 5(1):71-95.

Türkiye İstatistik Kurumu (TÜIK) Haber Bülteni (2017a). "Adrese Dayalı Nüfus Kayıt Sistemi Sonuçları, 2016", Sayı 24638, 31 Ocak 2017. http://www.tuik.gov.tr/PreHaberBultenleri.do?id=24638 (03.03.2017).

Türkiye İstatistik Kurumu (TÜIK) Haber Bülteni. (2017b). "İģücü İstatistikleri, Kasım 2016”, Say1: $\quad 24624, \quad 15 \quad$ Şubat 2017. http://www.tuik.gov.tr/PreHaberBultenleri.do?id=24624 (03.03.2017).

Üçok, D. ve Torun, A. (2015). "Örgütsel Sessizliğin Nedenleri Üzerine Nitel Bir Araştırma", İş ve İnsan Dergisi, 2(1):27-37.

Van Dyne, L., Ang, S. and Botero, I. C. (2003). "Conceptualizing Employee Silence and Employee Voice as Multidimensional Constructs", Journal of Management Studies, 40(6):1359-1392.

Vroom, V. H. (1964). “Work and Motivation”, New York: John Wiley \& Sons. 
Yılmaz, A., Bozkurt, Y. ve İzci, F. (2008). "Kamu Örgütlerinde Çalışan Kadın İşgörenlerin Çalışma Yaşamlarında Karşılaştıkları Sorunlar Üzerine Bir Araştırma", Eskişehir Osmangazi Üniversitesi Sosyal Bilimler Dergisi, 9(2):89-114. 